\title{
Taxonomic implications of pollen of some species of the genus Pterospermum Schreb. (Malvaceae s.l. subfam. Dombeyoideae)
}

\author{
Muhammad Amirul Aiman Ahmad Juhari* (1), Noraini Talip ${ }^{2}$ (D), Che Nurul Aini Che Amri ${ }^{3}$ (D), Nur Syazwani \\ Mohamad Basir ${ }^{2}$ (1), Mohamad Ruzi Abdul Rahman² (1), Ahmad Fitri Zohari² (D), Mohd Norfaizal Ghazali ${ }^{4}$ (1) \\ and Nordahlia Abdullah Siam ${ }^{5}$ (i)
}

Received: October 9, 2020

Accepted: November 29, 2020

\begin{abstract}
A palynological study of six species of Pterospermum was conducted to investigate variation in pollen micromorphological characteristics. The studied species were P. diversifolium, P. elongatum, P. jackianum, P. javanicum, P. lanceifolium and P. subpeltatum. Pollen was subjected to acetolysis, single-grain techniques and dehydration series, and observed using light and scanning electron microscopy. The results reveal some common characters shared by all the studied species, namely: echinate-granulate exine ornamentation; porate pollen class; and circular amb. Variation was found in the ratio of exine thickness, pollen size, and average spine length, outline, shape, measurements, spine size and the presence of an annulus. These characters proved to be valuable for identifying and differentiating the studied species. This study shows that morphological characteristics of Pterospermum pollen have taxonomic value, especially for the identification and differentiation of species of the subfamily Dombeyoideae and even other Malvaceae s.l.
\end{abstract}

Keywords: Dombeyoideae, Malvaceae, Malaysia, palynology, pollen morphology, Pterospermum

\section{Introduction}

Pterospermum which is also known as bayur or banyur in Malaysia is a medium-sized tree with stout, rounded buttresses and pale, pink-brown smooth to shallowly fissured bark surface (Ashton 1988). There are about 20 species of Pterospermum that can be found in tropical and subtropical regions of Asia including Thailand, India, Myanmar, Taiwan, China, Indo-China and Malesia (Wilkie \& Berhaman 2011). Reportedly, there are only eight species of Pterospermum in Malaysia with six of them are available in Peninsular Malaysia, namely Pterospermum acerifolium,
Pterospermum diversifolium, Pterospermum jackianum, Pterospermum javanicum, Pterospermum lanceifolium and Pterospermum pecteniforme. (Turner 1995). Member of this genus can be found on fertile clay-rich soils of well-drained alluvium, riverbanks, gullies and damp hillsides. The timber from this genus has equivalent strength properties to the lighter red meranti but is less durable in ground contact. It is also said to be fit for pulping through drastic treatment bleaching to produce silky appearance papers (Ashton 1988). In addition, the timber of Pterospermum species is usually used in construction and production of furniture (Wilkie \& Berhaman 2011).

1 Department of Environment, Faculty of Forestry and Environment, Universiti Putra Malaysia, 43400 UPM Serdang, Selangor, Malaysia

2 Department of Biological Sciences and Biotechnology, Faculty of Science and Technology, Universiti Kebangsaan Malaysia, 43600 UKM Bangi, Selangor, Malaysia

3 Department of Plant Science, Kuliyyah of Science, International Islamic University Malaysia, Bandar Indera Mahkota, 25200 Kuantan, Pahang, Malaysia

4 Programme of Resource Utilisation and Agrobiodiversity Conservation, Agrobiodiversity and Environment Research Centre, 43400, MARDI

Serdang, Malaysia

5 Forest Product, Forest Research Institute Malaysia, 52109 Kepong, Selangor

*Corresponding author: amirulaimanahmad@upm.edu.my 
The circumscription of Malvaceae has been very much debated as the traditional Malvaceae sensu stricto comprises of a very homogenous and cladistically monophyletic group (Perveen \& Qaiser 2009). Recently, Malvaceae sensu lato has been defined according to some closely related families which are Malvaceae, Tiliacae, Sterculiaceae and Bombacaceae. These families are merged into an expanded family Malvaceae s.l. by Judd \& Manchester (1997), Bayer et al. (1999) and Bayer \& Kubitzki (2003), to be further divided into nine subfamilies of Byttnerioideae, Grewioideae, Helicteroideae, Sterculideae, Brownlowioideae, Dombeyoideae, Malvoideae, Bombacoideae and Tilioideae (Perveen \& Qaiser 2009). Former genera in Sterculiaceae are now divided and distributed into four subfamilies: Byttnerioideae, Helicteroideae, Sterculoideae and Dombeyoideae according to recent classification by Bayer et al. (1999). Meanwhile, molecular study on Malvales by Bayer et al. (1999) suggested that Pterospermum belongs to the Malvaceae s.l. subfamily; Dombeyoideae. According to Ashton (1988), the identification of Pterospermum species can be very perplexing as many species manifest sapling, stipule and leaf characters that are very dissimilar from those of the matured trees. Smaller flowers in younger trees lead to description of immature materials of distinct species.

Studies on pollen morphology of Sterculiaceae (Malvaceae s.l) have been conducted by many researchers such as Wodehouse (1935), Selling (1947), Rao (1950), Erdtman (1952), Ikuse (1956), Chaudhuri \& Mallik (1965), Litchfield (1966), Sharma (1967), Cristobal (1968), Melhem et al. (1976), Robyns et al. (1977), Moore et al. (1991), Lakshmi (2003), Saba et al. (2004), El Husseini (2006), Perveen \& Qaiser (2009) and Hamdy \& Shamso (2010). Previous study by Perveen \& Qaiser (2009) managed to recognize two distinct pollen types in the subfamily Dombeyoideae from Pakistan that are based on the length of polar axis.

Previous report on the pollen grains of Pterospermum by Ya (1992) revealed that the pollen is spheroidal, amb circular, 3-porate, and exine spiny. The pollen appears closer to Dombeyeae but differs from Helictereae where the pollen is 3-porate or 3-3-colporate, amb triangular or subcircular, and exine reticulate (Ya 1992). This genus needs to be revised as it has no modern monographic treatment (Wilkie \& Berhaman 2011). Due to the taxonomic importance of the Malvaceae family and the need for studies to support the circumscription of the group, which remains uncertain, pollen morphology must be characterized in order to support the taxonomic studies of the group (Abreu et al. 2014). Therefore, the objective of this study is to investigate and characterize the pollen morphology of six Malaysian Pterospermum species using observations under light microscope (LM) and scanning electron microscope (SEM) to add more taxonomic information of the genus.

\section{Materials and methods}

For this study, dried pollen samples from six Pterospermum species, namely P. diversifolium Blume, P. elongatum Korth., P. jackianum Wall., P. javanicum Jungh., P. lanceifolium Roxb. and P. subpeltatum C.B.Rob were used. Samples were collected from Herbarium specimens of Forest Research Institute Malaysia (KEP), Malaysia and Royal Botanic Gardens Kew Herbarium (K), United Kingdom based on the availability of flower buds. Only one sample was available for each species except for P. diversifolium and P. subpeltatum.

The dried materials examined were as follows: Pterospermum subpeltatum C.B.Rob. BORNEO. Sarawak: Batang Rajang, 08/08/1938, Daud \& Tachun SFN 35727 (KEP); BORNEO. Sabah: Elapura, Sandakan, 18/03/1948, Anthony A 762 (KEP). P. jackianum Wall. MALAYA. Kedah: Bedong, Sungai Petani, 08/06/1926, T. Guard, Meh KEP 8976 (KEP). P. lanceifolium Roxb. MALAYA. Kedah: Kampung Masjid, Changlun, 23/05/1941, Jaamat \& Sow KEP 57017 (KEP). P. javanicum Jungh. MALAYA. Selangor: Sungai Buloh Forest Reserve, 11/04/1918, Hamid FMS 1579 (KEP). P. elongatum Korth. BORNEO. Sabah: Sandakan, 09/04/1935, Castro 4419 (K). P. diversifolium Blume. BORNEO. Sabah: Keningau, 23/04/1989, Fidilis K SAN 127667 (KEP); BORNEO. Sabah: Tenom, 22/05/1964, Rundi M 43189 (K); BORNEO. Sabah: Negeri Bubul Forest Reserve, Sempoerna, 25/09/1947, Harvey A 143 (KEP).

The pollen samples were first treated using acetolysis technique modified from Erdtman (1969) before being viewed under Scanning Electron Microscope (SEM) model Carl Zeiss Supra 55vp and photographed under Light Microscope (LM) using digital camera (Olympus BX43F) mounted on the Olympus microscope DP72 (Olympus Soft Imaging Solutions)/Cell^B Software, under 40x and 60x magnifications. Meanwhile, flower buds were softened in boiling water. Under dissecting microscope, anthers were dissected, crushed and separated. Using 1\% Teepol, flowers buds were cleaned and centrifuged for five minutes. Glacial acetic acid was added and centrifuged for another five minutes. Acetolysis mixture were then added into the samples and preheated on the hot plate around $70{ }^{\circ} \mathrm{C}$ until the pollen turned dark and the mixture of acetolysis turned to brown. The samples were cleansed after being centrifuged for five minutes using glacial acetic acid. Next, $2.5 \% \mathrm{KOH}$ solution was added and centrifuged. The pollen samples were then cleansed by using distilled water. The process was repeated two times to ensure total removal of the glacial acetic acid. The pollen samples were then dehydrated in a series of graded alcohol: $35,50,70,85,95 \%$ for 10 minutes each, followed by three times dehydration in $100 \%$ alcohol, prior to a critical point drying (CPD) process using drying machines model Polaron CPD 7501 and gold coating process using gold coater model BioRad SC500. For LM technique, the pollens were mounted onto the glass 
slides by using glycerine jelly and covered by glass slip. Single-grain technique following Zetter (1989) was also used in this study. At least 30 pollen grains were measured for each species to verify the stability of the data obtained. The analysis was done using unweighted pair group method with arithmetic mean (UPGMA) by MVSP version 3.2 Kovach to see the similarities among the studied species. The characters used for the analysis were polar length, equatorial length, $\mathrm{P} / \mathrm{E}$ ratio, pollen shape, aperture, amb, exine ornamentation, exine thickness ratio, pollen class, pollen size, spine length, spine width, spine shape, distance between spine and the presence of annulus. The description of pollen morphology followed Faegri \& Iversen (1992), Erdtman (1969), Hesse et al. (2009), Halbritter et al. (2018) and Amirul-Aiman et al. (2019).

\section{Results}

Findings show some similarities and differences in pollen morphological characteristics of the six Pterospermum species studied. All species have porate pollen grains and circular amb. The pollen morphology under SEM observations can be seen in Figure 1 and Figure 2. Meanwhile, the pollen morphology under LM observations is shown in Figure 3. Summary of variation found in this study is given in Table 1. Cluster analysis using unweighted pair group method with arithmetic mean (UPGMA) on the six species of Pterospermum studied is shown in Figure 4.

\section{Pollen morphological characteristics under LM and SEM}

Pterospermum diversifolium (Figs. 1A, 2A, 3A-B)

Pollen size: large. Polarity: isopolar. Dispersal unit: monad. Class: porate. P/E ratio: 0.94 . Shape: oblate-spheroidal. Aperture: triporate. Amb: circular. Exine thickness: $1.36(2.13 \pm 0.38) 2.85 \mu \mathrm{m}$. Exine ornamentation: tectum echinate-granulate, microgranulate; microspines and baculum present on the exine surface; annulus (thickening of exine) presents clearly around the pore; spines uniformly distributed with indistinct perforated base, slightly rounded tip. Exine thickness ratio (Exine/E): 0.04. Size: measurements from polar view (P) $52.69(58.14 \pm 0.36) 62.88 \mu \mathrm{m}$, measurements from equatorial view (E) $59.63(62.11 \pm 0.28) 65.46 \mu \mathrm{m}$, spine length $2.50(2.91 \pm 0.15) 3.30 \mu \mathrm{m}$, spine width 1.89 (2.23 \pm 0.13$) 2.61 \mu \mathrm{m}$, distance between spine 2.35 (3.96 $\pm 0.47) 5.98 \mu \mathrm{m}$.

Pterospermum elongatum (Figs. 1B, 2B, 3C-D)

Pollen size: large. Polarity: isopolar. Dispersal unit: monad. Class: porate. P/E ratio: 1.01 . Shape: prolate-spheroidal. Aperture: triporate. Amb: circular. Exine thickness: $1.32(1.86 \pm 0.35) 2.67 \mu \mathrm{m}$. Exine ornamentation: tectum echinate-granulate, microgranulate and microspines present; annulus (thickening of exine) presents clearly around the pore; spines uniformly distributed with indistinct perforated base, slightly sharp tip. Exine thickness ratio (Exine/E): 0.03. Size: measurements from polar view (P) 58.24 (65.24 $\pm 0.57) 70.13 \mu \mathrm{m}$, measurements from equatorial view (E) $61.65(64.74 \pm 0.29) 67.86 \mu \mathrm{m}$, spine length $1.36(2.00 \pm$ $0.24) 2.90 \mu \mathrm{m}$, spine width $1.12(1.47 \pm 0.15) 1.81 \mu \mathrm{m}$, distance between spine $4.12(7.22 \pm 0.84) 11.47 \mu \mathrm{m}$.

Pterospermum jackianum (Figs. 1C, 2C, 3E-F)

Pollen size: medium-large. Polarity: isopolar. Dispersal unit: monad. Class: porate. P/E ratio: 0.97 . Shape: oblate-spheroidal. Aperture: triporate. Amb: circular. Exine thickness: $0.93(2.53 \pm 0.61) 3.27 \mu \mathrm{m}$. Exine ornamentation: tectum echinate-granulate-perforate, microgranulate; annulus (thickening of exine) presents clearly around the pore; spines uniformly distributed with indistinct perforated base, slightly rounded tip. Exine thickness ratio (Exine/E): 0.04. Size: measurements from polar view (P) $44.85(54.15 \pm 0.44) 60.45 \mu \mathrm{m}$, measurements from equatorial view (E) $49.74(55.88 \pm 0.41) 62.18 \mu \mathrm{m}$, spine length $1.76(2.33 \pm 0.17) 2.82 \mu \mathrm{m}$, spine width 1.43 $(1.87 \pm 0.18) 2.27 \mu \mathrm{m}$, distance between spine 3.67 (4.72 $\pm 0.42) 7.01 \mu \mathrm{m}$.

Pterospermum javanicum (Figs. 1D, 2D, 3G-H)

Pollen size: medium. Polarity: isopolar. Dispersal unit: monad. Class: porate. P/E ratio: 1.19 . Shape: subprolate. Aperture: triporate. Amb: Convex triangular - circular. Exine thickness: $0.55(0.93 \pm 0.33) 1.53 \mu \mathrm{m}$. Exine ornamentation: tectum echinate-granulate, microgranulate; annulus (thickening of exine) presents clearly around the pore; spines uniformly distributed with indistinct perforated base, slightly oval tip. Exine thickness ratio (Exine/E): 0.02. Size: measurements from polar view (P) $37.02(43.03 \pm 0.61) 47.42 \mu \mathrm{m}$, measurements from equatorial view (E) $29.57(36.28 \pm 0.58) 42.79 \mu \mathrm{m}$, spine length $1.06(1.82 \pm 0.26) 2.36 \mu \mathrm{m}$, spine width 0.88 (1.04 \pm 0.11$) 1.36 \mu \mathrm{m}$, distance between spine 1.44 (2.61 $\pm 0.38) 3.95 \mu \mathrm{m}$.

Pterospermum lanceifolium (Figs. 1E, 2E, 3I-J)

Pollen size: medium. Polarity: isopolar. Dispersal unit: monad. Class: inaperturate. P/E ratio: 1.15 . Shape: subprolate. Aperture: triporate. Amb: circularspheroidal. Exine thickness: $0.55(0.83 \pm 0.38) 1.37$ $\mu \mathrm{m}$. Exine ornamentation: tectum echinate-granulate, microgranulate; annulus (thickening of exine) presents clearly around the pore; spines scarcely distributed with indistinct perforated base, slightly slender with almond shape tip. Exine thickness ratio (Exine/E): 0.02. Size: measurements from polar view (P) 38.76 (43.86 \pm 0.39$)$ $47.5 \mu \mathrm{m}$, measurements from equatorial view (E) 34.94 $(38.22 \pm 0.22) 40.01 \mu \mathrm{m}$, spine length $3.13(4.50 \pm 0.33)$ $5.73 \mu \mathrm{m}$, spine width $2.26(2.63 \pm 0.15) 3.12 \mu \mathrm{m}$, distance between spine $3.82(5.28 \pm 0.45) 7.40 \mu \mathrm{m}$. 
Pterospermum subpeltatum (Figs. 1F, 2F, 3K-L)

Pollen size: large. Polarity: isopolar. Dispersal unit: monad. Class: porate. P/E ratio: 0.98. Shape: oblate-spheroidal. Aperture: triporate. Amb: circular. Exine thickness: $1.64(2.73 \pm 0.41) 3.93 \mu \mathrm{m}$. Exine ornamentation: tectum echinate-granulate, microgranulate, annulus absent, spines uniformly distributed with indistinct perforated base, slightly sharp tip. Exine thickness ratio (Exine/E): 0.04. Size: measurements from polar view (P) $53.30(61.52 \pm 0.58)$ $69.55 \mu \mathrm{m}$, measurements from equatorial view (E) 56.29
(62.67 \pm 0.48$) 70.68 \mu \mathrm{m}$, spine length $1.43(2.19 \pm 0.33)$ $3.17 \mu \mathrm{m}$, spine width $1.40(1.58 \pm 0.09) 1.74 \mu \mathrm{m}$, distance between spine $3.29(4.41 \pm 0.59) 7.52 \mu \mathrm{m}$.

The unweighted pair-group method with arithmetic mean (UPGMA) was conducted using the pollen characteristics such as polar length, equatorial length, $\mathrm{P} / \mathrm{E}$ ratio, pollen shape, aperture, amb, exine ornamentation, exine thickness ratio, pollen class, pollen size, spine length, spine width, spine shape, distance between spine and the presence of annulus. The dendogram result is shown in Figure 4.

\section{Dichotomous key of Pterospermum species identification is constructed using pollen morphological characteristics observed in this study}

1a. Monad, triporate, isopolar, medium to large and large size pollen grains

1b. Monad, triporate, isopolar and medium size pollen grains

2a. Prolate-spheroidal pollen shape index

P. elongatum

2b. Oblate-spheroidal pollen shape index

3a. Absence of annulus around the pore of the pollen

P. subpeltatum

$3 \mathrm{~b}$. Presence of annulus around the pore of the pollen

4

4a. Tectum echinate-granulate and microgranulate exine ornamentation

P. diversifolium

4b. Tectum echinate-granulate and perforate exine ornamentation

P. jackianum

5a. Convex triangular-circular pollen amb, average spine length on pollen less than $3.00 \mu \mathrm{m}$

P. javanicum

5b. Circular-spheroidal pollen amb, average spine length on pollen more than $3.00 \mu \mathrm{m}$

P. lanceifolium

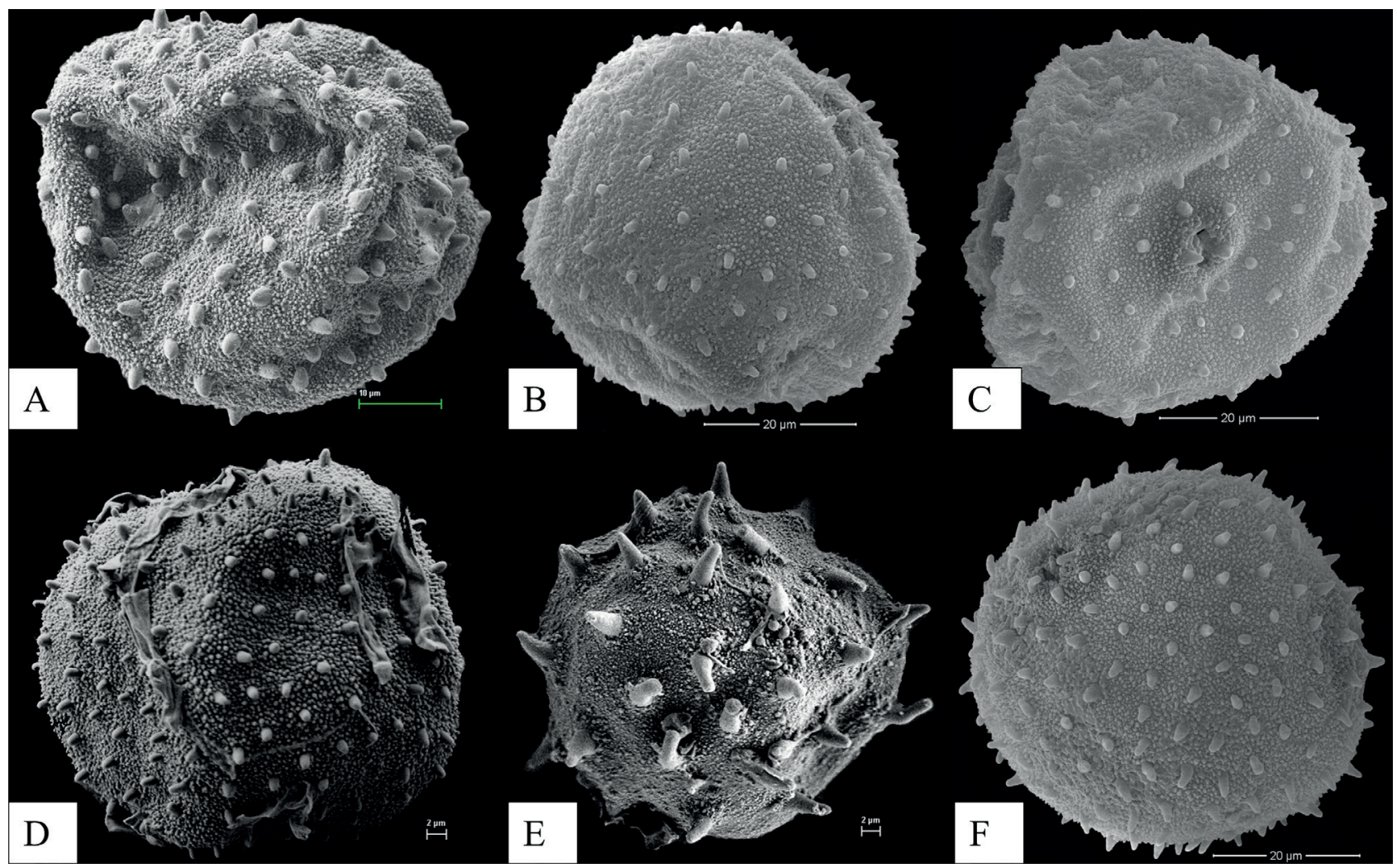

Figure 1. Pollen grains of Pterospermum (Malvaceae s.l.) under scanning electron microscope: A) Pterospermum diversifolium. B) Pterospermum elongatum. C) Pterospermum jackianum. D) Pterospermum javanicum. E) Pterospermum lanceifolium. F) Pterospermum subpeltatum. 


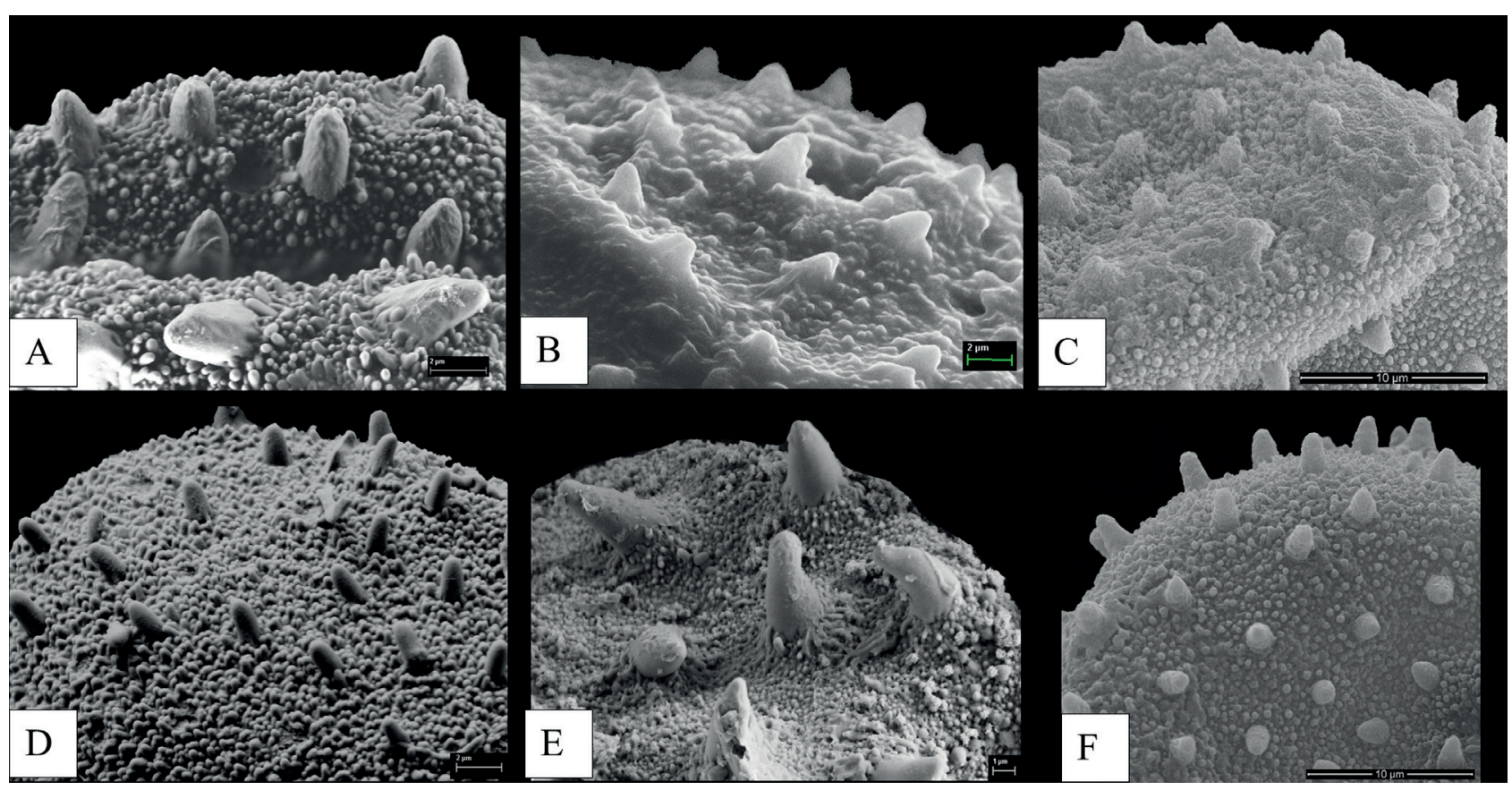

Figure 2. Pollen grains exine ornamentation of Pterospermum (Malvaceae s.l.) under scanning electron microscope: A) Pterospermum diversifolium. B) Pterospermum elongatum. C) Pterospermum jackianum. D) Pterospermum javanicum. E) Pterospermum lanceifolium. F) Pterospermum subpeltatum.

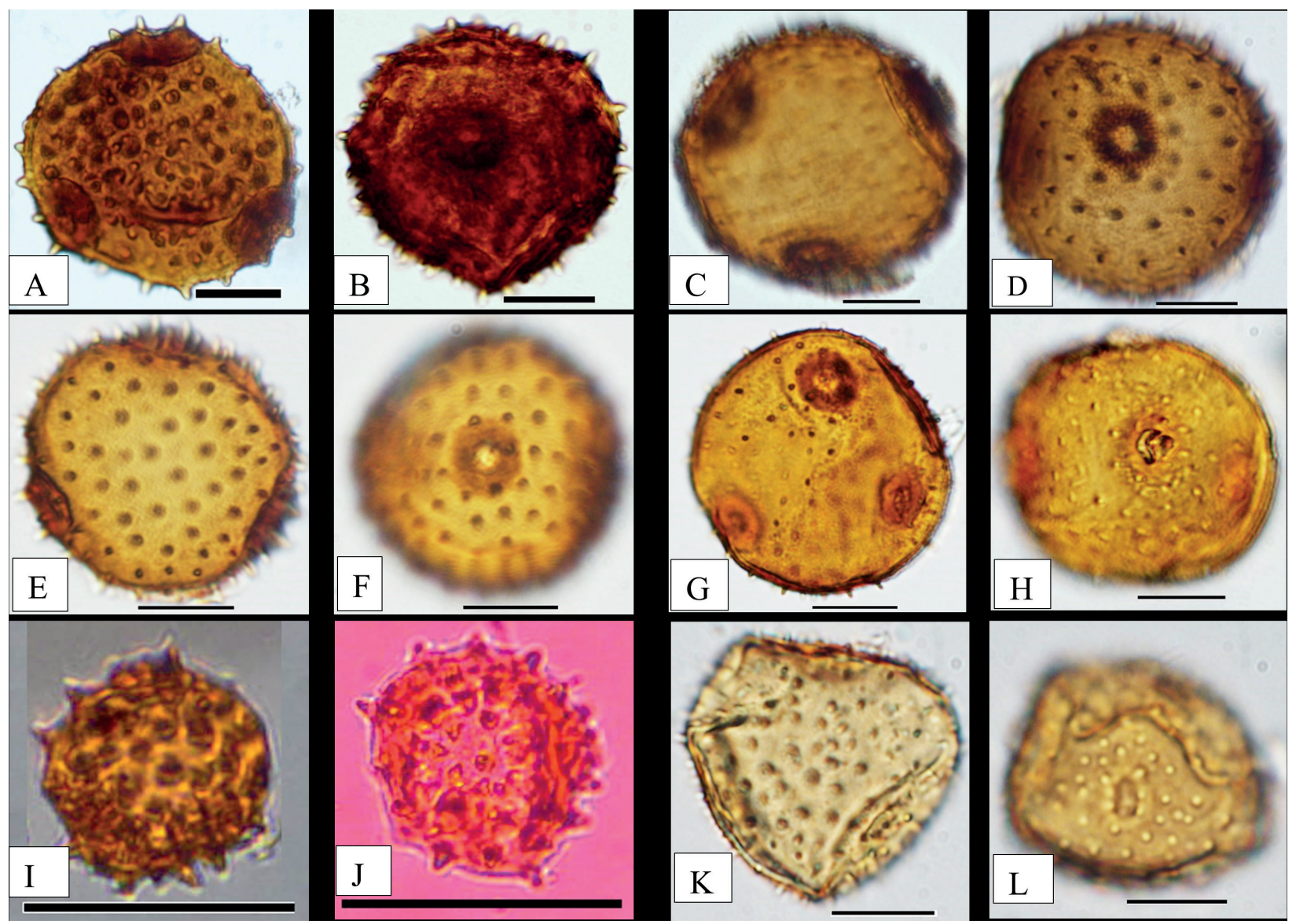

Figure 3. Polar and equatorial view of pollen of Pterospermum (Malvaceae s.l.) grains under light microscope: A-B) Pterospermum diversifolium. C-D) Pterospermum elongatum, E-F) Pterospermum jackianum, G-H) Pterospermum javanicum, I-J) Pterospermum lanceifolium. K-L) Pterospermum subpeltatum (Scale bar $=\mathbf{A}-\mathbf{B}, \mathbf{G}-\mathbf{L}=20 \mu \mathrm{m} ; \mathbf{C}-\mathbf{F}=50 \mu \mathrm{m}$ ). 


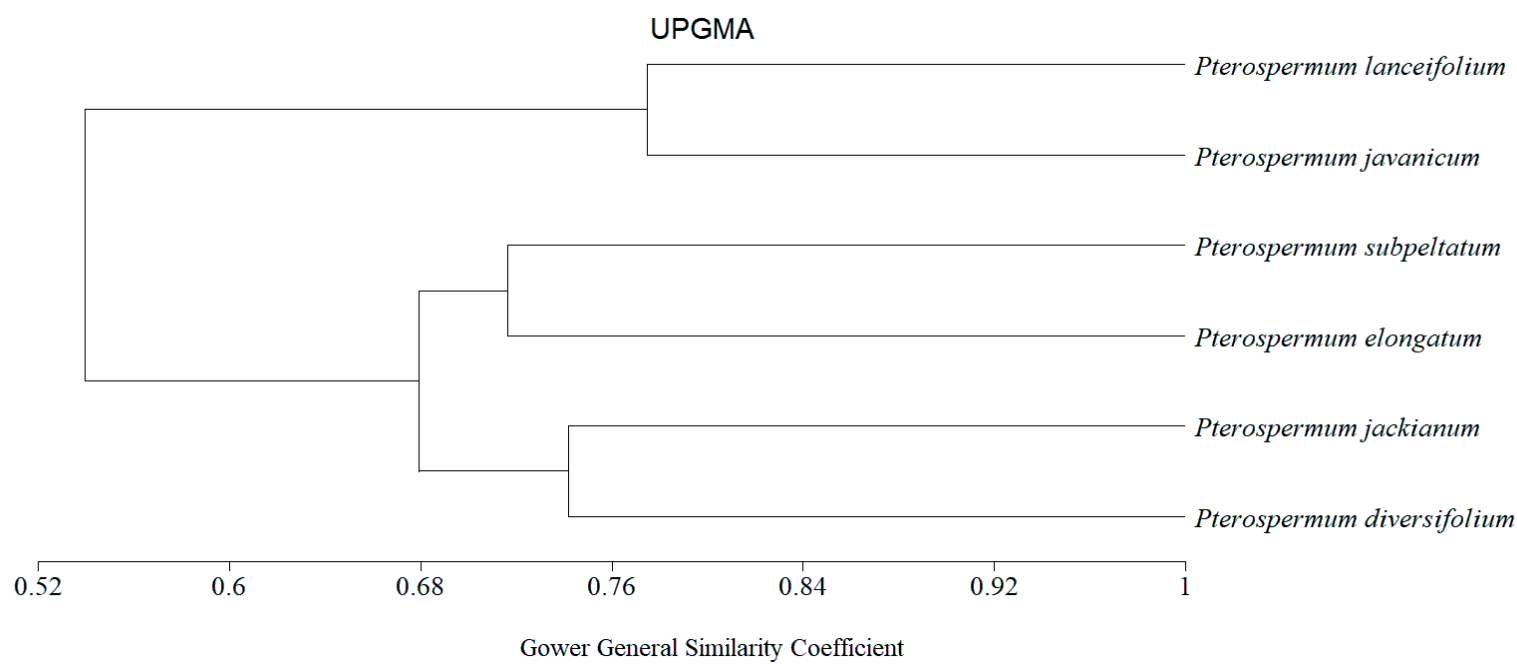

Figure 4. UPGMA cluster analysis on six species of Pterospermum using the pollen morphological characteristics.

Table 1. Summary of variations in pollen morphological characteristics in Pterospermum species studied.

\begin{tabular}{|c|c|c|c|c|c|c|}
\hline Pollen morphology & P. diversifolium & P. elongatum & P. jackianum & P. javanicum & P. Ianceifolium & P. subpeltatum \\
\hline Class & Porate & Porate & Porate & Porate & Porate & Porate \\
\hline Aperture & Triporate & Triporate & Triporate & Triporate & Triporate & Triporate \\
\hline Shape & Oblate-spheroidal & prolate-spheroidal & Oblate-spheroidal & Subprolate & Subprolate & Oblate-spheroidal \\
\hline $\mathrm{Amb}$ & Circular & Circular & Circular & $\begin{array}{c}\text { Convex triangular - } \\
\text { Circular }\end{array}$ & Circular - spheroidal & Circular \\
\hline Size & $\begin{array}{l}52-65 \mu \mathrm{m} \\
\quad \text { (large) }\end{array}$ & $\begin{array}{l}\text { *58-70 } \mu \mathrm{m} \\
\text { (large) }\end{array}$ & $\begin{array}{c}40-60 \mu \mathrm{m} \\
\text { (medium to large) }\end{array}$ & $\begin{array}{c}30-48 \mu \mathrm{m} \\
\text { (medium) }\end{array}$ & $\begin{array}{c}35-48 \mu \mathrm{m} \\
\text { (medium) }\end{array}$ & $\begin{array}{l}50-70 \mu \mathrm{m} \\
\text { (Large) }\end{array}$ \\
\hline $\mathrm{P} / \mathrm{E}$ value & 0.94 & 1.01 & 0.97 & 1.19 & 1.15 & 0.98 \\
\hline $\begin{array}{l}\text { Average spines } \\
\text { length }(\mu \mathrm{m})\end{array}$ & $2.79 \pm 0.27 \mu \mathrm{m}$ & $2.00 \pm 0.24$ & $2.33 \pm 0.17$ & $1.82 \pm 0.26$ & ${ }^{*} 4.50 \pm 0.33$ & $2.19 \pm 0.33$ \\
\hline $\begin{array}{c}\text { Average Distance } \\
\text { between spines }(\mu \mathrm{m})\end{array}$ & $3.96 \pm 0.47$ & $7.22 \pm 0.84$ & $4.72 \pm 0.42$ & $2.61 \pm 0.38$ & $5.28 \pm 0.45$ & $4.41 \pm 0.59$ \\
\hline Exine ornamentation & $\begin{array}{l}\text { Echinate-granulate, } \\
\text { microgranulate, } \\
\text { microspine and } \\
\text { baculum present }\end{array}$ & $\begin{array}{l}\text { Echinate-granulate, } \\
\text { microgranulate and } \\
\text { microspines present }\end{array}$ & $\begin{array}{l}\text { Echinate-granulate- } \\
\text {-perforate, micro- } \\
\text { granulate }\end{array}$ & $\begin{array}{l}\text { Echinate-granulate, } \\
\text { microgranulate }\end{array}$ & $\begin{array}{l}\text { Echinate-granulate, } \\
\text { microgranulate }\end{array}$ & $\begin{array}{l}\text { Echinate-granulate, } \\
\text { microgranulate }\end{array}$ \\
\hline Annulus & $\begin{array}{l}\text { Present clearly } \\
\text { around the pore }\end{array}$ & $\begin{array}{l}\text { Present clearly } \\
\text { around the pore }\end{array}$ & $\begin{array}{l}\text { Present clearly } \\
\text { around the pore }\end{array}$ & $\begin{array}{l}\text { Present clearly } \\
\text { around the pore }\end{array}$ & $\begin{array}{l}\text { Present clearly } \\
\text { around the pore }\end{array}$ & Absent \\
\hline $\begin{array}{l}\text { Exine thickness ratio } \\
\text { (Exine/E) }\end{array}$ & 0.04 (small) & 0.03 (small) & 0.04 (small) & 0.02 (small) & 0.02 (small) & 0.04 (small) \\
\hline $\begin{array}{c}\text { Average equatorial } \\
\text { diameter }(\mu \mathrm{m})\end{array}$ & $\begin{array}{c}59.63(62.11 \pm 0.28) \\
65.46 \mu \mathrm{m}\end{array}$ & $\begin{array}{c}61.65(64.74 \pm 0.29) \\
67.86\end{array}$ & $\begin{array}{c}49.74(55.88 \pm 0.41) \\
62.18\end{array}$ & $\begin{array}{c}29.57(36.28 \pm 0.58) \\
42.79\end{array}$ & $\begin{array}{c}34.94(38.22 \pm 0.22) \\
40.01\end{array}$ & $\begin{array}{c}56.29(62.67 \pm 0.48) \\
70.68\end{array}$ \\
\hline $\begin{array}{l}\text { Average polar } \\
\text { axis }(\mu \mathrm{m})\end{array}$ & $\begin{array}{c}52.69(58.14 \pm 0.36) \\
62.88 \mu \mathrm{m}\end{array}$ & $\begin{array}{c}58.24(65.24 \pm 0.57) \\
70.13\end{array}$ & $\begin{array}{c}44.85(54.15 \pm 0.44) \\
60.45\end{array}$ & $\begin{array}{c}37.02(43.03 \pm 0.61) \\
47.42\end{array}$ & $\begin{array}{c}38.76(43.86 \pm 0.39) \\
47.50\end{array}$ & $\begin{array}{c}53.30(61.52 \pm 0.58) \\
69.55\end{array}$ \\
\hline
\end{tabular}

*Highest value

\section{Discussion}

All species were collected as dried samples and also in harmomegathy condition. Hence, most pollens appear to be flattened and dehydrated. Our findings demonstrated that the dispersal unit of the pollen grains is monad while the pollen polarity is isopolar. This is parallel with the study performed by Hamdy \& Shamso (2010), where the pollen grains of Sterculiaceae are monads, radially symmetrical, isopolar as well as showing reliable variations in size, shape, exine sculpture and type of aperture. This is also supported by previous study on the genus Byttneria by Amirul-Aiman et al. (2019) where all species are monad.

The Pterospermum species can be separated on the basis of several characteristics such as exine ornamentation, pollen size and pollen shape. The absence of annulus on pollen of P. subpeltatum separates the species from other species. This character is considered as diagnostic characteristic that can be used for identification. In addition, the spine 
distribution can be used for delimitation of species. The presence of microspines on pollen exine of P. elongatum and the presence of baculum on pollen exine of $P$. diversifolium act as diagnostic characteristics to separate the species from others. Notably, the average spine length of $P$. lanceifolium is the longest among Pterospermum in this study. This character is useful to delimitate this species from other species.

One class of pollen is classified for all Pterospermum species studied which is porate. The aperture for these porate pollens is trizonoporate or triporate. This is in line with the study done by Hamdy \& Shamso (2010), where the subfamily Dombeyoideae consists of trizonoporate or triporate pollen aperture. Besides, the pollen shape ranges from oblate-spheroidal to subprolate. Based on the pollen shape classified by Erdtman (1952), the pollen shape is determined using ratio between polar axis and equatorial diameter of the pollen. Previous study on other genus in Sterculiaceae s.l.revealed that the pollen structure of Byttneria is triporate with small to medium size of pollen, as the shape of pollen ranges from oblate to spheroidal (Amirul-Aiman et al. 2019).

Hamdy \& Shamso (2010) mentioned that the pollen size of Dombeyoideae is large. In this study, the pollen of P. elongatum has the largest pollen size among these six species while $P$. javanicum has the smallest pollen size. However, the pollen size in this study ranges from $30-70 \mu \mathrm{m}$, where it falls under the range of medium, medium to large and large in size. According to Erdtman (1946), pollen size is considered as small when its size is below than $25 \mu \mathrm{m}$.

Furthermore, this study discovered that the sizes of pollen grains under LM and SEM are different. The size of pollen grains viewed under SEM is smaller than the size viewed under LM. This might be due to the shrinking or reduction in size of pollen grains during the acetolysis procedure and critical point drying procedure prior to SEM observation (Mohd-Arrabe' \& Noraini 2013). Wodehouse effect or generally known as harmomegathy effect is also the reason why the pollen sizes differ under LM and SEM. Pollen morphology can change to accommodate the pressure changes within the pollen grains in response to dry and wet conditions (Hesse et al. 2009). Phuphumirat et al. (2018) studied on the pollen morphology and harmomegathic character of Gnetum species. They found that the sizes of dehydrated and hydrated pollen were different. Similarly, the pollen size of Byttneria was affected by the harmomegathic effect as reported by Amirul-Aiman et al. (2019).

The pollen exine ornamentations found in this study are echinate-granulate, microgranulate and perforate. Hesse et al. (2009) stated that this type of echinate exine ornamentation consists of pointed element that is longer or wider than $1 \mu \mathrm{m}$. Punt et al. (2007) and Erdtman (1952) suggested the term 'spinose' to define spines that are longer than $3 \mu \mathrm{m}$ and 'spinules' for the smaller characters. Our findings also supported the study by Hamdy \& Shamso (2010) that reported the echinate-granulate exine ornamentation of Pterospermum acerifolium. There is also a variation between the distances of spines for each studied species. The pollen of P. elongatum has the highest average spine distance while P. javanicum has the shortest one. This character can also be used as species classification and identification tool.

Based on the cluster analysis performed using the pollen characteristics, it was found that two clusters are separated at the similarity coefficient of 0.54. P. lanceifolium is closer to P. javanicum with similarity coefficient of 0.775 but they are separated from other four species. This might be because these two species share the same pollen size group which is medium size pollen as compared to other Pterospermum. They also have the same pollen shape which is subprolate. The other cluster consists of pollen with circular amb and large pollen size except $P$. jackianum (medium to large in pollen size). In this second cluster, two subclads are formed. P. subpeltatum and P. elongatum are separated from $P$. jackianum and $P$. diversifolium with similarity coefficient of 0.679 . We predict that this two subclads are divided due to the tip shape of the spine. Both P. subpeltatum and P. elongatum have slightly sharp spine tip while P. jackianum and $P$. diversifolium have slightly round spine tip.

Perveen \& Qaiser (2009) in their findings on pollen study of two species of Melhania (Dombeyoideae) explained that their two species were divided into two pollen types based on the polar length. They also explained that the pollen of Dombeyoideae is more or less stenopalynous where the pollen grains are usually triporate, spheroidalsub-oblate along with echinate tectum with the variation in polar length. Previously, the family Sterculiaceae has been divided by Erdtman (1952) into eight pollen types which are Eriolaeneae, Fremontodendreae, Dombeyeae, Hermannieae, Byttnerieae, Lasiopetaleae, Helictertereae and Sterculieae.

On the basis of our data, we conclude that several pollen characters can be considered as the diagnostic characteristics in pollen delimitation. The results obtained also show that pollen morphological characteristics have some taxonomic values that can be used especially in identification and differentiation of species in Pterospermum. Further study should be conducted to understand the differences and similarities of more species under the same genus and subfamilies. More species and genus under the Malvaceae need to be added in order to support or discard the treatment of Sterculiaceae, Tiliaceae, Bombacaceae and Malvaceae as a separate family rather than the merging of these families based on molecular data, as observed by Judd \& Manchester (1997), Bayer et al. (1999) and Bayer \& Kubitzki (2003). In conclusion, this study has shown that pollen morphological characteristics of Pterospermum have taxonomic values that can be used especially in identification and differentiation of species in subfamily Dombeyoideae as well as in the family of Malvaceae s.l.. 


\section{Muhammad Amirul Aiman Ahmad Juhari, Noraini Talip, Che Nurul Aini Che Amri, et al.}

\section{Acknowledgements}

We thank Herbarium of Forest Research Institute Malaysia, Kepong (KEP) and Herbarium Royal Botanic Garden, Kew (Kew) for samples and Faculty of Science and Technology, Universiti Kebangsaan Malaysia for providing the facilities to conduct this study. We also thank Scanning Electron Microscopy Unit FST UKM and Centre of Research Institute and Management (CRIM). Authors also thank RIGS 16-095-0259 Grant (IIUM), GUP-2017-035 (UKM) and GP-IPM/2021/9697300 for the funding provided. Special thanks for Ministry of Higher Education Malaysia and Universiti Putra Malaysia.

\section{References}

Abreu VHRD, Mendonça CBF, Gonçalves-Esteves V. 2014. Pollen morphology of selected species of the subfamily Bombacoideae (Malvaceae sensu lato). Acta Botanica Brasilica 28: 352-360.

Amirul-Aiman AJ, Noraini T, Nurul-Aini CAC, Chung R, Phupumirat W, Ruzi A, Bunawan H, Idris H, Suhaniza R. 2019. Pollen Morphology and Harmomegathic Characters of Byttneria Löfl. Species (Sterculiaceae S.S: Subfam. Byttnerioideae). Malaysian Applied Biology 48: 19-26.

Ashton PS. 1988. Sterculiaceae. Manual of the Non-Dipterocarp Trees of Sarawak. Kuala Lumpur, Dewan Bahasa dan Pustaka.

Bayer C, Fay MF, De Bruijn AY, et al. 1999. Support for an expanded family concept of Malvaceae: A combined analysis of plastid atpB and $\mathrm{rbcL}$ DNA sequences. Botanical Journal of the Linnean Society 129: 267-303.

Bayer C, Kubitzki K. 2003. Malvaceae. In: Kubitzki K, Bayer C. (eds.) The Families and Genera of Vascular Plants. Vol. 5. Berlin, Springer. p. 225-311.

Chaudhuri SK, Mallik N. 1965. Pollen morphological studies of the order Malvales. Bulletin of the Botanical Society of Bangladesh 19: 32-39.

Cristobal CL. 1968. Estudio morfologico de les granas de polen de Byttneria. Pollen et Spores 10: 57-72.

El-Husseini N. 2006. Pollen morphology of Tiliaceae Juss. and Sterculiaceae Vent. and their relations to Malvaceae Juss. in Egypt. International Journal of Agriculture and Biology (Pakistan) 8: 844-847.

Erdtman G. 1946. Pollen morphology and plant taxonomy VI. On pollen and spore formulae. Vol. 1. Uppsala, Svensk Bot Tidskrift.

Erdtman G. 1952. Pollen morphology and plant taxonomy angiosperms. Stockholm, Almqvist and Wiksell.

Erdtman G. 1969. Handbook of palynology: morphology, taxonomy, ecology, an introduction to the study of pollen grains and spores. New York, Hafner Publishing Co.

Faegri K, Iversen J. 1992. Textbook of pollen analysis. 2nd. edn. Chichester, John Wiley \& Sons.

Halbritter H, Ulrich S, Grimsson F, et al. 2018. Illustrated pollen terminology. Gewerbestrasse, Springer International Publishing.

Hamdy R, Shamso E. 2010. Pollen morphology of Sterculiaceae (s. str.) in Egypt and its taxonomic significance. Egyptian Journal of Botany 50: 103-117.
Hesse M, Halbritter H, Weber M, et al. 2009. Pollen terminology: an illustrated handbook. Vienna, Springer Science \& Business Media.

Ikuse M. 1956. Pollen grains of Japan. Tokyo, Hirokawa Publishing Cooperation.

Judd WS, Manchester SR. 1997. Circumscription of Malvaceae (Malvales) as determined by a preliminary cladistic analysis of morphological, anatomical, palynological and chemical characters. Brittonia 4: 384405.

Lakshmi GK. 2003. Palynological studies on certain Malvales. PhD Thesis, Mahatma Gandhi University, Kottayam Kerala.

Litchfield WH. 1966. The pollen morphology of Australian Sterculiaceae. Pollen et Spores 8: 439-453.

Melhem ISA, Silvestre MSF, Lucas NMC. 1976. Pollen morphological studies in Sterculiaceae. Hoehnea (Brazil) 6: 23-32.

Mohd-Arrabe' AB, Noraini T. 2013. Pollen morphology of Rhizophora L. in Peninsular Malaysia. American Institute of Physics Conference Proceedings 1571: 377-381.

Moore PD, Webb JA, Collinson M. 1991. Pollen Analysis. London, Blackwell Hall.

Perveen A, Qaise M. 2009. Pollen Flora of Pakistan-MalvaceaeDombeyoideae-LXII. Pakistan Journal of Botany 41: 491-494.

Phuphumirat W, Leeratiwong C, Malaikanok P, Zetter R. 2018. Morphological and harmomegathic characters of pollen of Gnetum species (Gnetaceae) in Thailand: studies with light and scanning electron microscopy. Botanical Journal of the Linnean Society 187: 653-671.

Punt W, Hoen PP, Blackmore S, Nilsson S, Le Thomas A. 2007. Glossary of pollen and spore terminology. Review of Palaeobotany and Palynology 143: 1-81.

Rao CV. 1950. Pollen grains of Sterculiaceae. The Journal of Indian Botanical Society 29: 130-137.

Robyns A, Nilsson S, Dechamps R. 1977. Sur la position systematique du genera Maxwellia Baillon. Bulletin du Jardin Botanique National de Belgique 47: 145-153.

Saba MD, Santos FA, Esteves GL. 2004. Palinotaxonomia das tribos Byttnerieae DC. Hermannieae DC. e Helictereae DC (Malvaceae s.l.) da flora da Bahia, Brasil. Hoehnea 31: 189-214.

Selling O. 1947. Studies in Hawaiian pollen statistics. Part 2: The pollen of Hawaiian phanerogams No. 38. Honolulu, University of Hawaii Press, Bishop Museum Special Publication.

Sharma BD. 1967. Studies of Indian pollen grains in relation to plant taxonomy- Sterculiaceae. Bulletin of the Botanical Survey of India 35: 320-359

Turner IM. 1995. A catalogue of the vascular plants of Malaya. The Gardens' Bulletin Singapore 47: 347-655.

Wilkie P, Berhaman A. 2011. Sterculiaceae s.l.. In: Soepadmo E, Saw LG, Chung RCK, Kiew R. (eds.) Tree Flora of Sabah and Sarawak. Vol. 7. Malaysia, Sabah Forestry Department, Forest Research Institute Malaysia (FRIM), Sarawak Forestry Department.

Wodehouse RP. 1935. Pollen Grains, their Structure, Identification and Significance in Science and Medicine. New York, MC Graw-Hill Book Cooperation.

Ya T. 1992. On the affinities of Pterospermum Schreb. (Sterculiaceae). Guihaia 12: 8-14.

Zetter R. 1989. Methodik und Bedeutung einer routinemaBig kombinierten lichtmikroskopischen und rasterelektronmikroskopischen Untersuchung Fossiler Mikrofloren. Courier Forschungsinstitut Senckenberg 109: 41-50. 